\title{
Article
}

\section{Achieving zero carbon targets in buildings without compromising health and wellbeing of occupants - a new FM research direction}

\author{
Liyanage, Champika Lasanthi and Hadjri, Karim
}

Available at http://clok.uclan.ac.uk/22717/

Liyanage, Champika Lasanthi ORCID: 0000-0001-6687-3611 and Hadjri, Karim ORCID: 0000-0001-8243-8396 (2015) Achieving zero carbon targets in buildings without compromising health and wellbeing of occupants - a new FM research direction. Journal of Facilities Management, 13 (3). ISSN 1472-5967

It is advisable to refer to the publisher's version if you intend to cite from the work. http://dx.doi.org/10.1108/JFM-05-2015-0014

For more information about UCLan's research in this area go to http://www.uclan.ac.uk/researchgroups/ and search for <name of research Group>.

For information about Research generally at UCLan please go to http://www.uclan.ac.uk/research/

All outputs in CLoK are protected by Intellectual Property Rights law, including Copyright law. Copyright, IPR and Moral Rights for the works on this site are retained by the individual authors and/or other copyright owners. Terms and conditions for use of this material are defined in the policies page.

\section{CLoK}

Central Lancashire online Knowledge www.clok.uclan.ac.uk

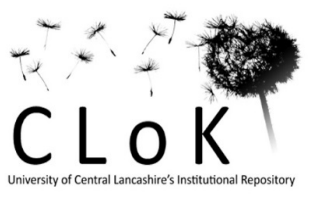




\title{
Achieving Zero Carbon Targets in Buildings without compromising Health and Wellbeing of Occupants - a New FM Research Direction
}

\author{
Champika Liyanage and Karim Hadjri \\ Grenfell-Baines School of Architecture, Construction and Environment, University of Central Lancashire, \\ Preston, PR1 2HE
}

The UK, through the Climate Change Act (2008), aims to ensure that the net UK carbon account for the year 2050 is at least $80 \%$ lower than the 1990 baseline. In order for this target to be realised, emissions from all sectors will have to be reduced, while at the same time renewable energy production is expected to increase. Currently, $\mathrm{CO}_{2}$ emissions and the energy use of buildings are controlled through Building Regulations and 'Approved Document Part L - Conservation of fuel and power' (Zero Carbon Hub, 2013), which came into force on 1st April 2002. The main target of Part L Building Regulations is to create a well-sealed envelope, coupled with the right amount of insulation in buildings. In energy terms, this is highly beneficial, as better-sealed and better-insulated buildings become more 'air tight', thus allowing low air permeability/leakages to minimise heat/energy loss. However, there is a concern that low air permeability in pursuit of energy efficiency can lead to a build-up of pollutants and/or to excessive moisture levels in some circumstances. According to Howieson et al. (2014), a building that is airtight, needs to have adequate ventilation. If not, insufficient air changes caused by reduced infiltrations may lead to poor Indoor Air Quality (IAQ) levels, which could lead to a build-up of indoor pollutants that are potentially dangerous to building occupants (Crump et al, 2009). Dampness is one of the most common pollutants found in buildings. The other common indoor air pollutants include $\mathrm{CO}, \mathrm{CO}_{2}, \mathrm{NO}_{2}$, odours, volatile organic compounds (VOCs), allergens, and mould (Energy Saving Trust, 2006). It is estimated that poor IAQ is responsible for around two million disability adjusted life years (DALYs) per year, which is about 3\% of the total burden of all diseases in Europe (EFA, 2013). Indoor air could be much more polluted than external air, and as people spend around $60-90 \%$ of their time indoor (Slezakova et al, 2012), even minor amounts of pollutants in airtight buildings can significantly increase the occupants' exposure to pollutants and may affect their health and wellbeing (WHO, 2009).

The Health and Safety Executive (HSE) estimates that between 30 and $50 \%$ of new or refurbished buildings lead to building-related illnesses (Zolfagharifard 2014). Building-related illnesses are disorders that affect the lungs as well as other parts of the body and are caused by exposure to indoor air pollutants present in airtight buildings that have poor ventilation (Jantunen et al., 2011). The most common symptoms of building-related illnesses are headaches, lethargy and poor concentration, asthma, skin irritation, dry itchy eyes, congested nose and allergies such as hay fever. In 2001, the Alberta Court of Appeal building (an 87-year old sandstone building) came under scrutiny when several judges, attorneys, and other staff suffered fatigue, irritated lungs and watery eyes following a renovation to bring the historic structure up to modern energy efficient standards. The investigations showed that the upgrades to the buildings had a downside. Reducing air leakages of the old building helped reduce energy costs, but without adequate vapour barriers and ventilation, according to air quality samples of the buildings, a toxic blend of mould grew in the walls, which led to building-related illnesses (Slezakova et al, 2012).

The above highlights a long-term problem that could potentially increases the burden of diseases and health costs. Although the building regulations and low/zero carbon targets are there to reduce energy consumption and to reduce the impact on climate change, more strategies are needed to ensure occupants' health and wellbeing. This provides a greater scope for facilities managers. The facilities manager's role herein is not only to ensure the operation and maintenance of buildings are carried out to 'save' energy, but also to ensure human (e.g. health) and environmental (e.g. IAQ) factors are taken into consideration. This requires examining ways of balancing human comfort and energy consumption during facilities design and post-occupancy stages. Therefore, it is timely FM research identify strategies that can improve environmental conditions in buildings to achieve zero carbon targets without compromising the health and wellbeing of occupants. This may raise the FM profession to greater heights of recognition in terms of the role it can play in the low or zero-carbon era and its relationship to public health. 


\section{References:}

1. Boardman, B. (2007) Home Truths: Executive Summary, University Of Oxford's Environmental Change Institute, A Research Report for the Co-Operative Bank and Friends of the Earth, Accessed on $31^{\text {st }}$ of July 2014 , Available at http://www.foe.co.uk/sites/default/files/downloads/home truths summary.pdf

2. British Standard Institute (BSI) (2002) BS 5250:2002: Code of practice for control of condensation in buildings. British Standard Institute, London.

3. Climate Change Act (2008) Chapter 27. London: The Stationery Office.

4. Crump, D., Dengel, A. \& Swainson, M. (2009) Indoor Air Quality in Highly Energy Efficient Homes A Review, NHBC Foundation Report NF19, IHS BRE Press, Watford, UK.

5. Energy Saving Trust (2006) Energy efficient ventilation in dwellings - a guide for specifiers. Report No. GPG268. Energy Saving Trust, London.

6. European Federation of Allergy and Airways Diseases Patients' Associations (EFA) (2013) Indoor Air Quality and its Effects on Health: a Presentation of the Guidelines for Health-Based Ventilation in Europe. Accessed on $12^{\text {th }}$ July 2013, Available at: http://www.efanet.org/wpcontent/uploads/2013/03/HealthVent-event-Report-FINAL.pdf

7. Halliday, S. (2009) Technical Paper 6: Indoor air quality and energy efficiency in traditional buildings. Technical Report. Historic Scotland, Technical Conservation Group. Accessed on $12^{\text {th }}$ July 2013, Available at: http://www.historic-scotland.gov.uk/traditional-buildings-air-quality-energy-efficiency.pdf

8. Howieson, S. G., Sharpe, T. and Farren, P. (2014) Building tight - ventilating right? ; How are new air tightness standards affecting indoor air quality in dwellings?, Building Services Engineering Research and Technology, 35 (5), pp. 475-487.

9. Jantunen M., Oliveira Fernandes E., Carrer P. and Kephalopoulos S. (2011) Promoting actions for healthy indoor air (IAIAQ). Report, European Commission Directorate General for Health and Consumers. Luxembourg.

10. Slezakova, K., Morais, S. \& do Carmo Pereira, M. (2012) Indoor Air Pollutants: Relevant Aspects and Health Impacts, Environmental Health - Emerging Issues and Practice, Prof. Jacques Oosthuizen (Ed.), ISBN: 978-953-307-854-0, InTech, DOI: 10.5772/30364. Accessed on 02 ${ }^{\text {nd }}$ July 2013, Available from: http://www.intechopen.com/books/environmental-health-emerging-issues-andpractice/indoor-air-pollutants-relevant-aspects-and-health-impacts-

11. World Health Organisation (WHO) (2009) WHO guidelines for indoor air quality: dampness and mould. World Health Organization Regional Office for Europe, Copenhagen. ISBN 978-92-890-41683 . Accessed on $12^{\text {th }}$ July 2013 , Available at http://www.euro.who.int/ data/assets/pdf file/0017/43325/E92645.pdf

12. Zero Carbon Hub (2013) Zero carbon strategies - For tomorrow's new homes, Accessed on $12^{\text {th }}$ Feb 2015, Available at http://www.foe.co.uk/sites/default/files/downloads/home truths summary.pdf

13. Zolfagharifard E. (2014) Are energy efficient homes making us ILL? Toxic mould caused by poor air circulation could trigger 'sick building syndrome, Mail [online] 18/02/2014. Accessed on $18^{\text {th }}$ of Feb 2014. Available from: http://www.dailymail.co.uk/sciencetech/article-2562146/Are-energy-efficienthomes-making-ILL-Toxic-mould-caused-poor-air-circulation-trigger-sick-building-syndrome.html 